\title{
Perancangan Permainan "UangAndro" Sebagai Media Pembelajaran Pengenalan Mata Uang Rupiah Pada Anak Berbasis Android
}

\author{
Siti Wulansari ${ }^{1)}$, Kodrat Imam Satoto ${ }^{2)}$, Kurniawan Teguh Martono ${ }^{2)}$ \\ Program Studi Sistem Komputer Fakultas Teknik Universitas Diponegoro \\ Jalan Prof. Sudharto, Tembalang, Semarang, Indonesia \\ wulansari840@gmail.com
}

\begin{abstract}
Abstrak - Untuk melatih dan meningkatkan kemampuan siswa dalam berhitung perlu adanya metode dan media pembelajaran yang baru. Dengan adanya metode dan pembelajaran baru diharapkan agar siswa dapat meningkatkan semangat dan minat dalam berhitung. Media yang digunakan untuk berhitung adalah mata uang rupiah. Melalui media mata uang rupiah tersebut dibangun sebuah aplikasi permainan "UangAndro" berbasis Android yang diharapkan siswa dapat lebih mudah untuk mengenal mata uang rupiah dan dapat melatih kemampuan dalam berhitung menggunakan media mata uang rupiah.

Perancangan permainan "UangAndro" dibuat menggunakan Construct 2. Construct 2 adalah sebuah game engine dengan grafik 2 dimensi berbasis html 5. Permainan ini dikembangkan dengan metode Multimedia Development Life Cycle (MDLC) yang bersumber dari Luther dan sudah dimodifikasi oleh Sutopo. Pengujian aplikasi permainan yang telah dibuat menggunakan metode black-box, pengujian ini dilakukan untuk memeriksa fungsi yang terdapat dalam aplikasi permainan. Pengujian ke pengguna dengan memberikan tes pada siswa-siswi. Data yang dihasilkan akan dianalisis menggunakan analisis regresi linier sederhana.
\end{abstract}

Aplikasi permainan "UangAndro" sebagai penegenalan mata uang rupiah yang dapat melatih kemampuan siswa dalam berhitung menggunakan media mata uang rupiah sudah berhasil dirancang dan dibangun menggunakan Construct 2. Berdasarkan pengujian blackbox, menunjukkan bahwa permainan sudah berjalan sesuai spesifikasi kebutuhan yang menampilkan hasil uji pada tiap fungsi aplikasi dan tombol. Pada uji hipotesis yaitu uji $F$ dan uji $t$, dapat disimpulkan bahwa model regresi yang dihasilkan cocok dan adanya pengaruh nyata (signifikan) variabel lama belajar terhadap variabel hasil belajar.

Kata Kunci: Permainan, UangAndro, Construct 2, MDLC, Black-box, Regresi Linier Sederhana, Hipotesis.

\section{PENDAHULUAN}

Teknologi pada masa sekarang ini telah menjadi salah satu aspek yang wajib ada dalam setiap sendi kehidupan umat manusia. Hal ini tidak lain karena keberadaannya yang memberikan kemudahan dalam segala aktivitas manusia. Termasuk dalam hal pembelajaran. Sistem pembelajaran yang konvensional pada bangku sekolahan umunya hanya menggunakan buku sebagai media pembelajaran. Dengan keberadaan teknologi, media pembelajaran dapat ditingkatkan menjadi lebih menarik dan lebih interaktif bagi siswa. Sehingga siswa menjadi lebih bersemangat dalam belajar dan siswa menjadi lebih mudah mengingat materi yang sedang dipelajari.

Salah satu materi pembelajaran yang ada pada siswa tingkat Sekolah Dasar kelas II adalah materi mengenai uang. Materi ini merupakan salah satu materi yang berhubungan langsung dengan kehidupan sehari-hari. Pada materi pembelajaran mengenai uang, siswa dituntut untuk mampu mengenal mata uang rupiah sebagai mata uang Republik Indonesia. Selain itu, siswa juga dituntut untuk memiliki kemampuan berhitung menggunakan mata uang Rupiah.

Pembelajaran melalui multimedia adalah salah satu hal yang berpangaruh dalam dunia pendidikan dengan memanfaatkan peran kemajuan teknologi saat ini. Multimedia adalah proses penggunaan komputer untuk menyajikan dan menggabungkan teks, suara, gambar, animasi, dan video dengan alat bantu (tool) dan berkomunikasi. Multimedia juga diadopsi oleh dunia game. Multimedia dimanfaatkan juga dalam dunia pendidikan dan bisnis. Di dunia pendidikan, multimedia digunakan sebagai sarana media pengajaran, baik dalam kelas maupun secara sendiri-sendiri ${ }^{[7]}$.

Game atau permainan yang merupakan bagian dari multimedia merupakan suatu alternatif hiburan bagi masyarakat baik orang dewasa maupun anak-anak. Salah satu ciri game untuk anak-anak adalah game yang menyisipkan nilai-nilai edukasi dalam permainannya. Game pada platform Android merupakan salah satu yang cukup populer, mengingat Android merupakan salah satu sistem operasi perangkat bergerak yang paling banyak digunakan masyarakat. Untuk itu, penulis merancang permainan interaktif pada Android dengan tema pendidikan yaitu mengenalkan mata uang rupiah bagi anak - anak tingkat Sekolah Dasar kelas II dengan cara yang menyenangkan dan mudah dipahami. Dengan adanya permainan pengenalan mata uang rupiah berbasis Android ini diharapkan untuk memberikan pengenalan tentang mata uang rupiah dan dapat melatih kemampuan anak dalam hal berhitung menggunakan media mata uang rupiah dalam proses pembelajaran dengan cara mengoptimalkan penggunaan sebuah perangkat selular yaitu tidak hanya untuk bermain tetapi juga sebagai sarana pembelajaran yang sangat mudah digunakan dimanapun.

\section{LANDASAN TEORI}

\section{A. Media Pembelajaran}

Media merupakan alat saluran komunikasi. Media dapat diibaratkan seperti televisi, diagram, bahan tercetak (printed materials), komputer, dan instruktur. Pembelajaran merupakan suatu kegiatan yang melibatkan seseorang dalam upaya memperoleh pengetahuan, keterampilan dan nilai-nilai 
positif dengan memanfaatkan berbagai sumber untuk belajar. Pembelajaran dapat melibatkan siswa sebagai pembelajar dan guru sebagai fasilitator. Yang terpenting dalam kegiatan pembelajaran adalah terjadinya proses belajar.

Media pembelajaran selalu terdiri dari atas dua unsur penting, yaitu unsur peralatan atau perangkat keras (hardware) dan unsur pesan yang dibawanya (message atau software). Dengan demikian, media pembelajaran memerlukan peralatan untuk menyajikan pesan, namun yang terpenting bukanlah peralatan itu, tetapi pesan atau informasi belajar yang dibawakan oleh media tersebut. Dari definisi di atas dapat diambil kesimpulan bahwa (a) media pembelajaran merupakan wadah dari pesan, (b) materi yang ingin disampaikan adalah pesan pembelajaran, (c) tujuan yang ingin dicapai ialah proses pembelajaran. Penggunaan media secara kreatif akan memperbesar kemungkinan bagi siswa untuk belajar lebih banyak, mencamkan apa yang dipelajarinya lebih baik, dan meningkatkan penampilan dalam melakukan keterampilan sesuai dengan yang menjadi tujuan pembelajaran ${ }^{[16]}$.

\section{B. Multimedia}

Multimedia merupakan kombinasi teks, seni, suara, animasi, dan video yang disampaikan kepada pengguna dengan komputer atau peralatan manipulasi elektronik dan digital yang lain. Multimedia dapat menimbulkan sensasi dahsyat. Ketika pengguna menggabungkan bersama semua elemen video sensual multimedia, menggabungkan gambar dan animasi, mempercantik suara, membuat video klip ${ }^{[18]}$.

Dari definisi diatas, sebuah sistem multimedia dapat digambarkan seperti pada gambar 1 .

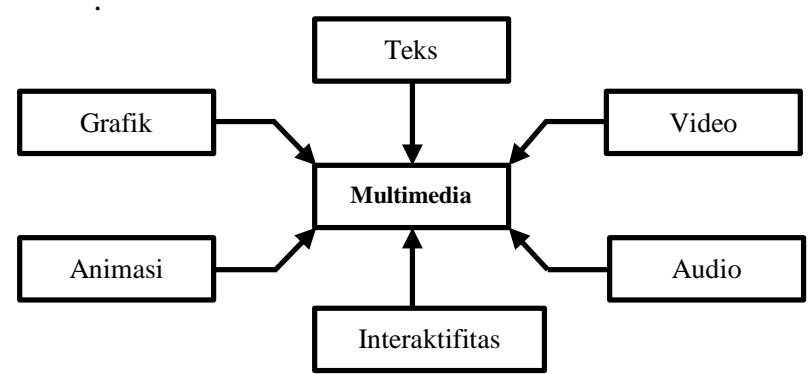

Gambar 1. Gambaran definisi multimedia ${ }^{[3]}$

Multimedia terbagi menjadi beberapa objek, antara lain :

1. Teks

Hampir semua orang yang biasa menggunakan komputer sudah terbiasa dengan teks. Teks merupakan dasar dari pengolahan kata dan informasi berbasis multimedia. Dalam kenyataannya multimedia menyajikan informasi kepada audiens dengan cepat, karena tidak diperlukan membaca secara rinci dan teliti.

2. Image atau grafik

Secara umum image atau grafik berarti still image seperti foto dan gambar. Manusia sangat berorientasi pada visual dan gambar merupakan sarana yang sangat baik untuk menyajikan informasi.

3. Animasi

Animasi adalah pembentukan gerakan dari berbagai media atau objek yang divariasikan dengan gerakan transisi, efek-efek, juga suara yang selaras dengan gerakan animasi tersebut atau animasi merupakan penayangan frame gambar secara cepat untuk menghasilkan kesan gerakan.

4. Audio

Penyajian audio atau suara merupakan cara lain untuk lebih memperjelas pengertian suatu informasi. Contohnya, narasi merupakan kelengkapan dari penjelasan yang dilihat melalui video. Suara dapat lebih menjelaskan karakteristik suatu gambar, misalnya musik dan efek suara (sound effect). Salah satu bentuk bunyi yang bisa digunakan dalam produksi multimedia adalah Waveform Audio yang merupakan format file audio yang berbentuk digital. Kualitas produknya bergantung pada sampling rate (banyaknya sampel per detik). Waveform (wav) merupakan standar untuk Windows PC.

5. Video

Video merupakan elemen multimedia paling kompleks karena penyampaian informasi yang lebih komunikatif dibandingkan gambar biasa. Walaupun terdiri dari elemen-elemen yang sama seperti grafik, suara dan teks, namun bentuk video berbeda dengan animasi. Perbedaan terletak pada penyajiannya. Dalam video, informasi disajikan dalam kesatuan utuh dari objek yang dimodifikasi sehingga terlihat saling mendukung penggambaran yang seakan terlihat hidup.

6. Interactive Link

Sebagian dari multimedia adalah interaktif, dimana pengguna dapat menekan mouse atau objek pada screen seperti button atau teks dan menyebabkan program melakukan perintah tertentu ${ }^{[1]}$.

\section{Metodologi Pengembangan Multimedia}

Metodologi yang digunakan adalah Multimedia Development Life Cycle (MDLC) yang bersumber dari Luther (1994) dan sudah dimodifikasi oleh Sutopo. Metodologi pengembangan multimedia tersebut terdiri dari enam tahap, yaitu konsep (concept), perancangan (design), pengumpulan materi (material collecting), pembuatan (assembly), pengujian (testing), dan distribusi (distribution). Keenam tahap ini tidak harus berurutan dalam prakteknya, tahap-tahap tersebut dapat saling bertukar posisi. Meskipun begitu, tahap konsep memang harus menjadi hal yang pertama kali dikerjakan $^{[1]}$.

Metodologi pengembangan multimedia Luther yang sudah dimodifikasi oleh Sutopo ditunjukkan pada Gambar $2^{[3]}$.

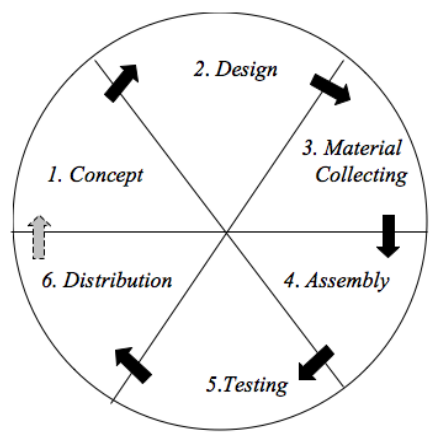

Gambar 2. Tahapan pengembangan multimedia. 


\section{1. $\operatorname{Konsep}($ Concept)}

Tahap konsep adalah tahap untuk menentukan tujuan dan siapa pengguna (identifikasi audiensi). Karena tujuan dan pengguna akhir dari program akan mempengaruhi konsep multimedia yang akan dibuat. Selain itu, ini akan menentukan jenis aplikasi (presentasi, interaktif, dan lain-lain) dan tujuan aplikasi(hiburan, pelatihan, pembelajaran dan lain-lain). Dasar aturan untuk perancangan juga ditentukan pada tahap ini, misalnya ukuran aplikasi, target, dan lain-lain.

\section{Perancangan (Design)}

Desain adalah tahap pembuatan spesifikasi mengenai arsitektur program, gaya, tampilan, dan alur program yang dapat disajikan dalam bentuk bagan alir (flowchart).

\section{Pengumpulan Materi (Material Collecting)}

Pengumpulan materi adalah tahap pengumpulan bahan yang sesuai dengan kebutuhan pembuatan aplikasi. Bahanbahan tersebut, antara lain materi yang akan dibahas, gambar, foto, animasi, dan audio.

\section{Pembuatan (Assembly)}

Pada tahap ini dilakukan pembuatan semua objek atau bahan multimedia. Pembuatan aplikasi didasarkan pada tahap perancangan. Untuk pembuatan aplikasi pada tahap ini biasanya menggunakan perangkat lunak seperti Adobe Photoshop dan Adobe Illustrator.

\section{Pengujian (Testing)}

Tahap pengujian dilakukan setelah menyelesaikan tahap pembuatan dengan menjalankan aplikasi/program dan melihat hasilnya apakah ada kesalahan atau tidak.

\section{Distribusi (Distribution)}

Pada tahap ini, aplikasi akan disimpan dalam suatu media penyimpanan. Jika media penyimpanan tidak cukup untuk menampung aplikasinya, maka kompresi terhadap aplikasi tersebut akan dilakukan. Tahap ini juga dapat disebut tahap evaluasi untuk pengembangan produk yang sudah jadi supaya menjadi lebih baik ${ }^{[4]}$.

\section{Pengenalan Mata Uang Rupiah}

Uang adalah suatu benda yang dapat ditukarkan dengan benda lain, dapat digunakan untuk menilai benda lain, dan dapat disimpan ${ }^{[13]}$

Spesifikasi mata uan rupiah terdiri dari mata uang

Rupiah berdasarkan bahan logam dan mata uang rupiah berdasarkan bahan $\operatorname{kertas}^{[7]}$

Pembelajaran mengenal mata uang rupiah pada anak usia dini penting untuk dapat menambah wawasan bagi anak. Terdapat banyak hal yang dapat dipelajari dari uang yaitu mengenal jenis uang, mengenal nominal uang, mengenal terbilang uang dan dapat belajar berhitung menggunakan uang. Proses pembelajaran untuk pengenalan uang ini dapat melalui multimedia. Dengan multimedia, proses pembelajaran akan menjadi lebih menarik, efektif dan lebih interaktif. Lembaga riset dan penerbitan komputer, yaitu Computer Technology Research (CTR) menyatakan bahwa orang hanya mampu mengingat $20 \%$ dari yang dilihat dan $30 \%$ dari yang didengar. Namun, mereka mengingat $50 \%$ dari yang dilihat sekaligus didengar dan sebanyak $80 \%$ dari yang dilihat, didengar, dan yang dilakukan sekaligus. Dengan demikian, multimedia menjadi perangkat ampuh untuk proses pengajaran dan pendidikan ${ }^{[17]}$.

\section{E. Sistem Operasi Android}

Android merupakan Sistem operasi yang gratis dan terbuka dari google yang berjalan diberbagai perangkat seperti telepon, tablet bahkan televisi. Terdapat banyak perangkat yang dapat digunakan dengan satu platform. Aplikasi Android secara Native dibangun menggunakan bahasa pemrogramman Java, namun pada perkembangannya kita dapat menggunakan bahasa pemrogramman berbasis Web dimana ini dimungkinkan dengan memanfaatkan Web View yang ada pada Android ${ }^{[12]}$.

\section{F. Perangkat Lunak Construct 2}

Construct 2 adalah produk buatan Scirra, perusahaan yang berasal dari London, Inggris. Construct 2 yang memang didesain dengan banyak fitur. Game builder ini sebenarnya dirancang untuk game berbasis $2 \mathrm{D}^{[7]}$.

\section{G. Audacity}

Audacity adalah aplikasi perangkat lunak untuk merekam dan menyunting suara. Aplikasi ini bersifat open source dan sehingga dapat berjalan pada berbagai sistem operasi.

Audacity mampu mengoreksi suara tertentu, atau sekedar menambahkan berbagai efek yang disediakan. Audacity juga digunakan untuk memotong suara, menambahan bahkan mengkonversi ke file lain, diantaranya MP3, Ogg, dan Wave ${ }^{[9]}$.

\section{H. Corel Draw X6}

CorelDRAW X6 merupakan software untuk membuat desain grafis yang sangat populer dan sudah diakui kecanggihannya. Kelengkapan fasilitas dan kemampuannya yang luar biasa dalam membuat suatu desain, menjadikan software ini banyak dipakai oleh para Desainer Grafis, karena keberadaannya benar-benar mampu membantu dan memudahkan pemakai dalam menyelesaikan berbagai jenis pekerjaan grafis ${ }^{[10]}$.

\section{Metode Pengumpulan Data}

Tes adalah sederetan pertanyaan atau latihan atau alat lain yang digunakan untuk mengukur keterampilan, pengetahuan, intelegensi, dan kemampuan atau bakat yang dimiliki oleh individu atau kelompok ${ }^{[8]}$. Tes diberikan setelah siswa menggunakan aplikasi permainan, tujuannya untuk mengukur pengaruh yang ada pada saat aplikasi permainan digunakan oleh siswa.

Metode pengujian aplikasi yang digunakan adalah metode Uji Kotak Hitam (Black Box Testing). Uji kotak hitam yaitu pengujian yang dilakukan untuk menunjukkan fungsi program yang dibuat tentang cara operasi dan kegunaannya, apakah keluaran data sesuai dengan yang diharapkan. Hasil pengujian ke pengguna yaitu lama belajar menggunakan aplikasi permainan dengan hasil belajar dari siswa akan dianalisis menggunakan analisis regresi linier sederhana dan melakukan uji hipotesis. Secara umum, 
analisis regresi pada dasarnya adalah mengenai ketergantungan variabel dependen (terikat) dengan satu atau lebih variabel independen (variabel penjelas/bebas), dengan tujuan untuk memprediksi nilai rata-rata variabel dependen berdasarkan nilai variabel independen yang diketahui ${ }^{[6]}$. Keunggulan regresi adalah kemampuannya untuk membantu memberikan penjelasan secara statistik pengaruh variabelvariabel bebas terhadap variabel terikat ${ }^{[14]}$. Sedangkan uji hipotesis adalah suatu prosedur yang akan menghasilkan suatu keputusan, yaitu menerima atau menolak hipotesis tersebut $^{[11]}$.

\section{J. Teknik Analisis Data}

Untuk menganalisis data hasil pre-test dan post-test dilakukan langkah-langkah sebagai berikut :

1. Menghitung nilai hasil jawaban benar pada soal tes.

2. Membuat penyajian data hasil tes ke dalam bentuk tabel.

3. Menganalisis data menggunakan analisis regresi linier sederhana dengan bantuan software SPSS 16.

4. Memasukkan hasil analisis ke dalam persamaan analisis regresi sederhana sebagai berikut :

$$
\mathrm{Y}=\mathrm{a}+\mathrm{bX}
$$

5. Melakukan uji hipotesis dengan menentukan kriteria penerimaan dan penolakan hipotesis :

a. Jika signifikan $<0,05$, maka hipotesis nol $\left(\mathrm{H}_{0}\right)$ ditolak dan hipotesis alternatif $\left(\mathrm{H}_{1}\right)$ diterima.

b. Jika signifikan $>0,05$, maka hipotesis nol $\left(\mathrm{H}_{0}\right)$ diterima dan hipotesis alternatif $\left(\mathrm{H}_{1}\right)$ ditolak. ${ }^{[19]}$

\section{PERANCANGAN SISTEM}

A. Tahapan Pengembangan Multimedia

1. Konsep

Dalam tahap konsep yang perlu diperhatikan merumuskan dasar-dasar dari proyek multimedia yang akan dibuat dan dikembangkan menjadi hal yang utama yang sangat penting. Selain itu juga untuk menentukan macam aplikasi (presentasi, interaktif, dan lain lain) dan tujuan aplikasi (hiburan, pelatihan, pembelajaran).

Berdasarkan penjelasan singkat diatas. Konsep permainan uangandro berbasis Android ini dibuat untuk pembelajaran dasar dalam pengenalan uang rupiah untuk anak-anak tingkat Sekolah Dasar kelas II, sehingga mereka mudah memahami melalui cara yang interaktif. Aplikasi ini memiliki 3 bagian. Yang pertama bagian untuk pembelajaran, pada bagian ini terdapat gambar uang logam dan uang kertas. Yang kedua adalah mengingat uang rupiah, dalam proses mengingat dibuatlah sebuah permainan mencocokkan kotak teka-teki. Dimana di setiap levelnya 2 gambar yang dibuat acak dan tertutup. Yang ketiga adalah permainan, konsep dari permainan ini adalah berhitung dengan menggunakan media uang rupiah, dengan diberikan 3 level yaitu mudah, sedang, dan sulit. Setiap level terdiri soal perhitungan penjumlahan dan pengurangan sesuai dengan level yang dipilih oleh pengguna, kemudian pengguna akan memilih uang rupiah mana saja yang menjadi jawaban. Perbandingan level mudah, sedang, dan sulit terletak pada pewaktu dan soal perhitungan yang diberikan.
Permainan ini dapat dimainkan oleh semua kalangan dan jenis kelamin, namun lebih dikhususkan untuk anak-anak tingkat Sekolah Dasar kelas II, dengan harapan agar anak dapat mengenal uang rupiah dan lebih dapat melatih meningkatkan kemampuan berhitung menggunakan media mata uang rupiah. Anak-anak dilatih untuk belajar menyimak dengan baik dan teliti dalam menjawab soal perhitungan.

2. Desain atau Perancangan

Pada tahap desain atau perancangan permainan dimulai dengan membuat rancangan permainan melalui bagan untuk halaman тепи utama, perancangan permainan selanjutnya menggunakan use case dan sequence diagram, kemudian membuat desain tampilan permainan melalui storyboard.

Tahap awal dalam perancangan permainan ini dibuat sebuah bagan perancangan aplikasi yang berisi bagian-bagian dari aplikasi permainan. Bagan perancangan aplikasi ditunjukkan pada Gambar 3.

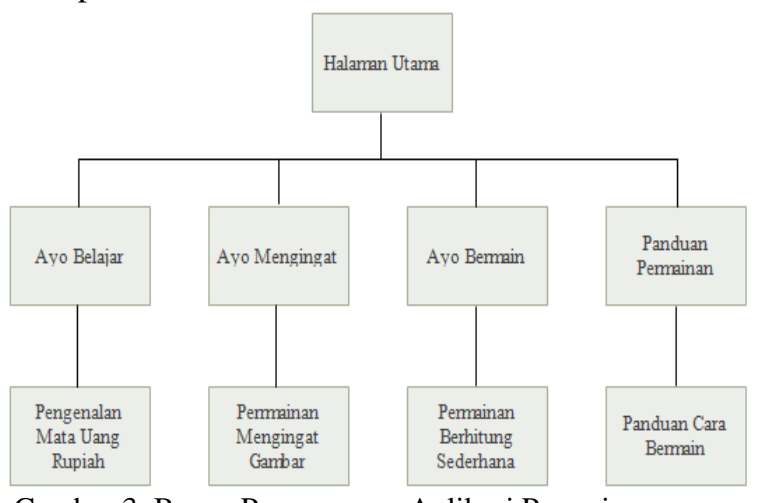

Gambar 3. Bagan Perancangan Aplikasi Permainan Gambar 4 menunjukkan use case diagram aplikasi permainan

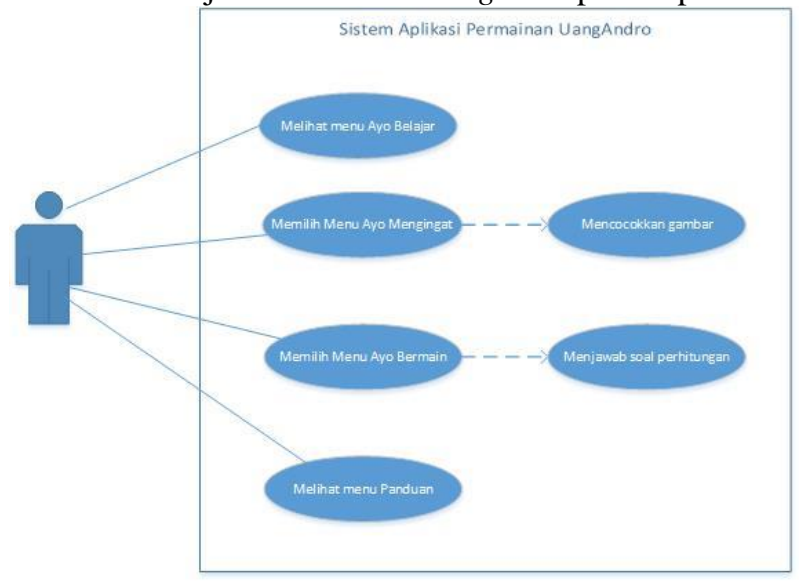

Gambar 4. Use case aplikasi permainan

Gambar 5 menunjukkan sequence diagram Ayo Belajar.

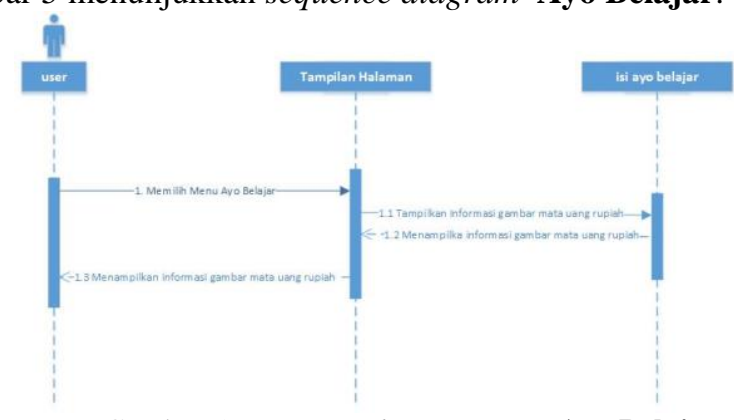

Gambar 5. Sequence diagram menu Аyo Belajar 
Gambar 6 menunjukkan sequence diagram pada menu Ayo Mengingat

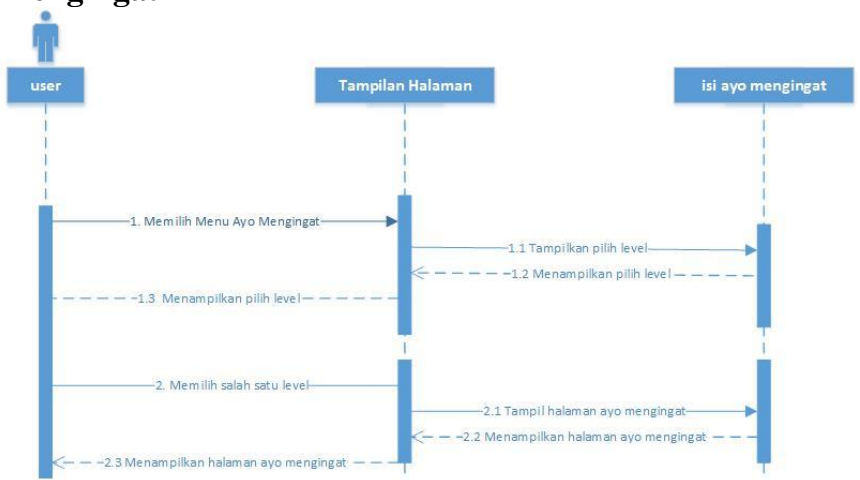

Gambar 6. Sequence diagram menu Ayo Mengingat

Gambar 7 menunjukkan sequence diagram pada menu Ауо Bermain.

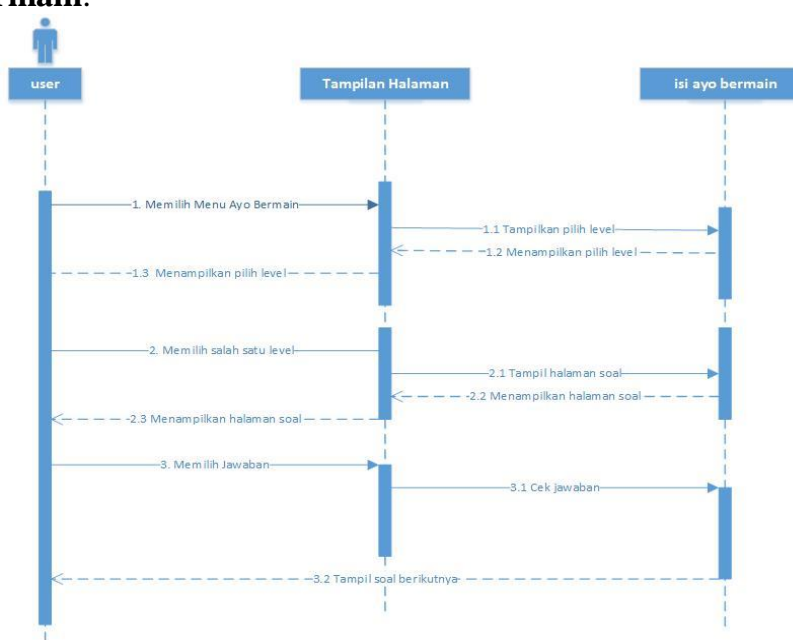

Gambar 7. Sequence diagram menu Ауо Bermain

Gambar 8 menunjukkan sequence diagram pada menu Panduan.

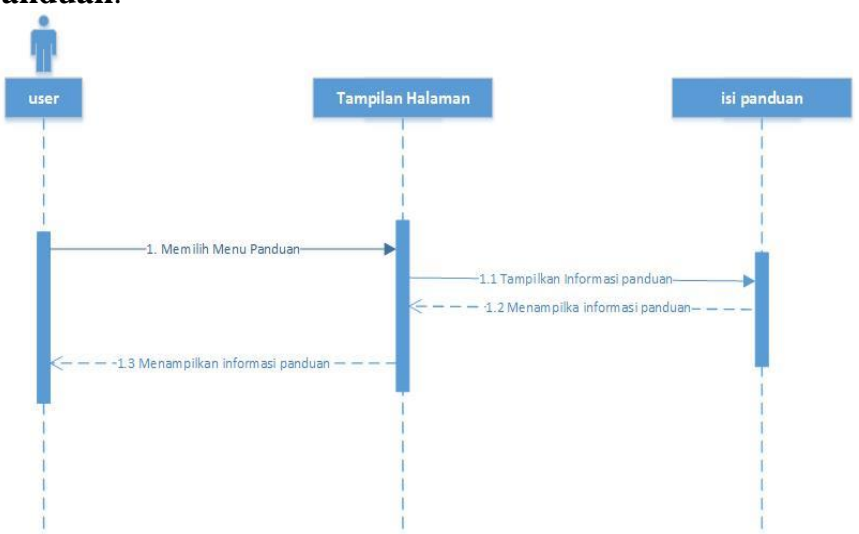

Gambar 8. Sequence diagram menu Ayo Bermain

Setelah dibuat sequence diagram untuk mengetahui alur permainan, selanjutnya dibuat desain tampilan aplikasi. Tampilan rancangan halaman тепи utama ditunjukkan oleh Gambar 9.

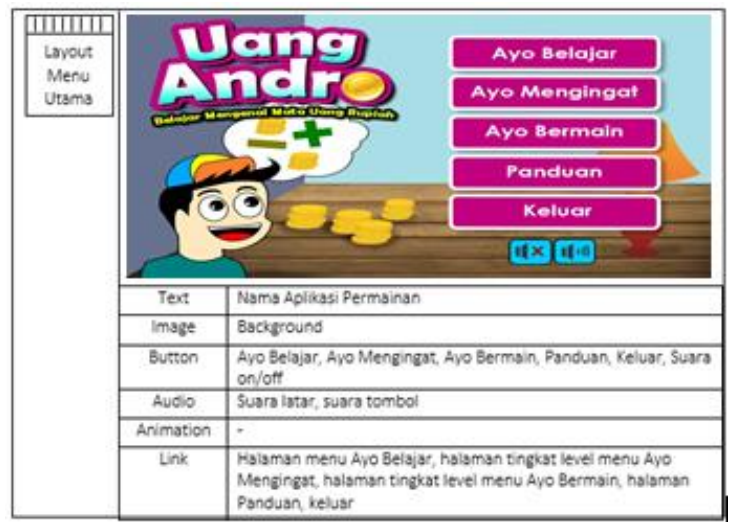

Gambar 9. Rancangan halaman menu utama

Tampilan rancangan halaman mеnи Ayo Belajar ditunjukkan oleh Gambar 10.

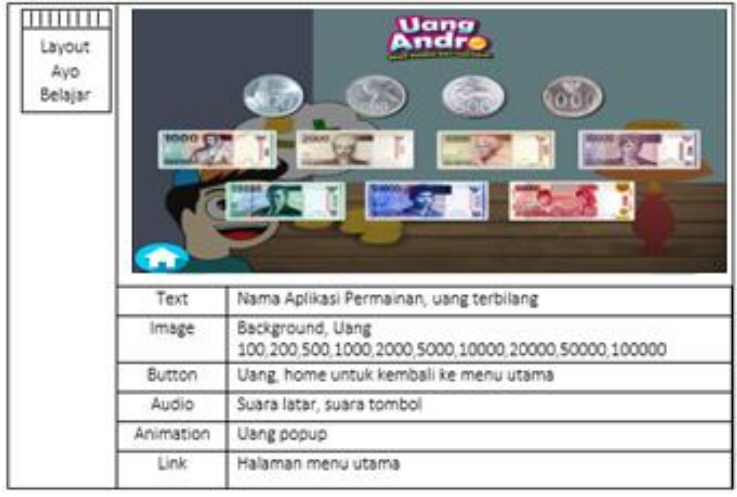

Gambar 10. Rancangan halaman menu Ayo Belajar

Tampilan rancangan halaman mепи pilih level Ayo Mengingat ditunjukkan oleh Gambar 11.

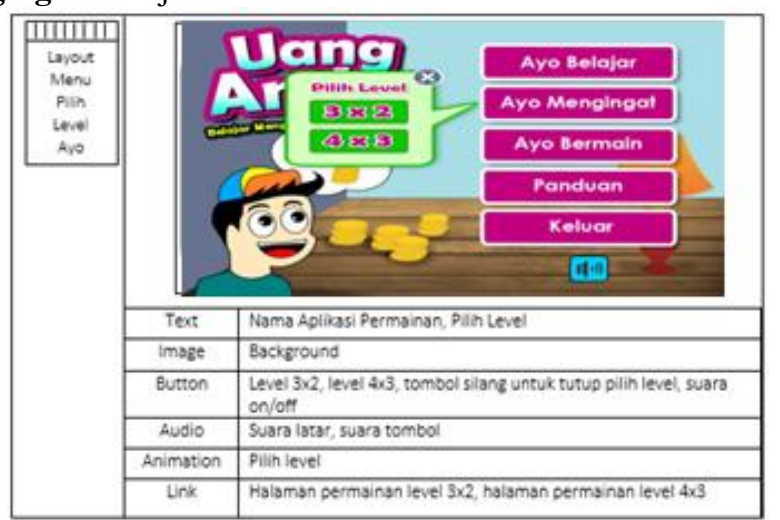

Gambar 11. Rancangan halaman тепи pilih level Ayo Mengingat

Tampilan rancangan halaman menu Ayo Mengingat Level 3x2 ditunjukkan oleh Gambar 12. 


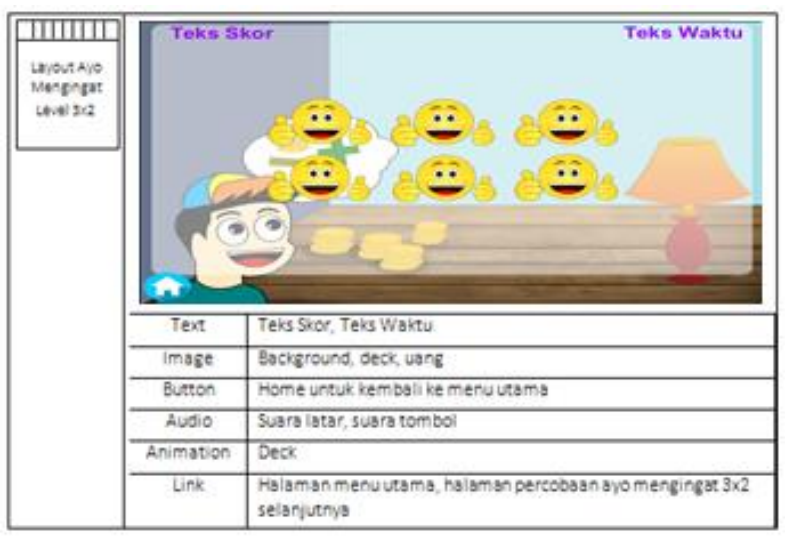

Gambar 12. Rancangan halaman menu Ayo Mengingat Level 3x2

Tampilan rancangan halaman mепи Ayo Mengingat Level 4x3 ditunjukkan oleh Gambar 13.

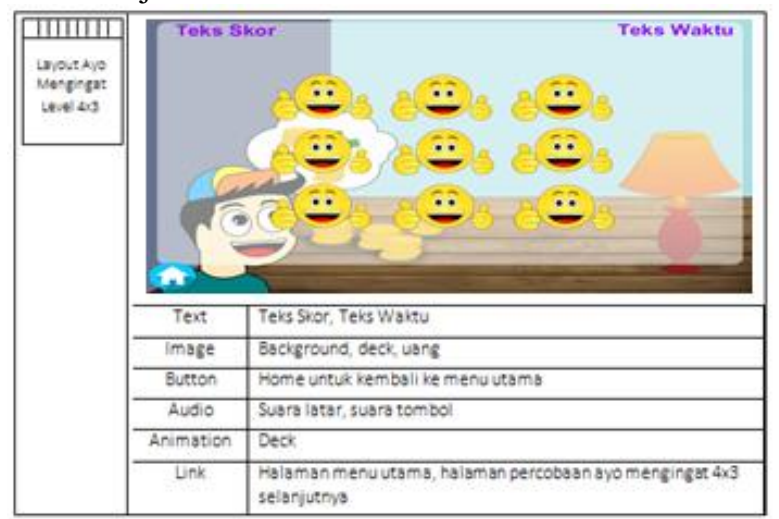

Gambar 13. Rancangan halaman menu Ayo Mengingat Level 4x3

Tampilan rancangan halaman menu pilih level Ayo

Bermain ditunjukkan oleh Gambar 14.

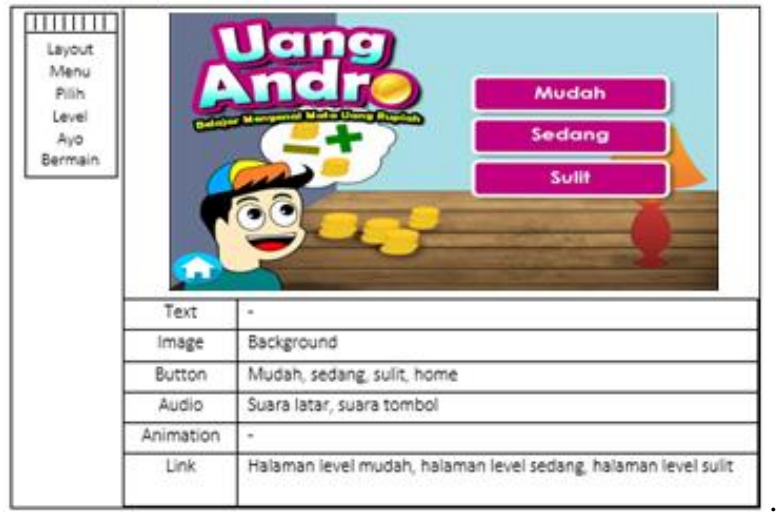

Gambar 14. Rancangan halaman mеnu pilih level Ayo Bermain

Tampilan rancangan halaman menu Ayo Bermain ditunjukkan oleh Gambar 15.

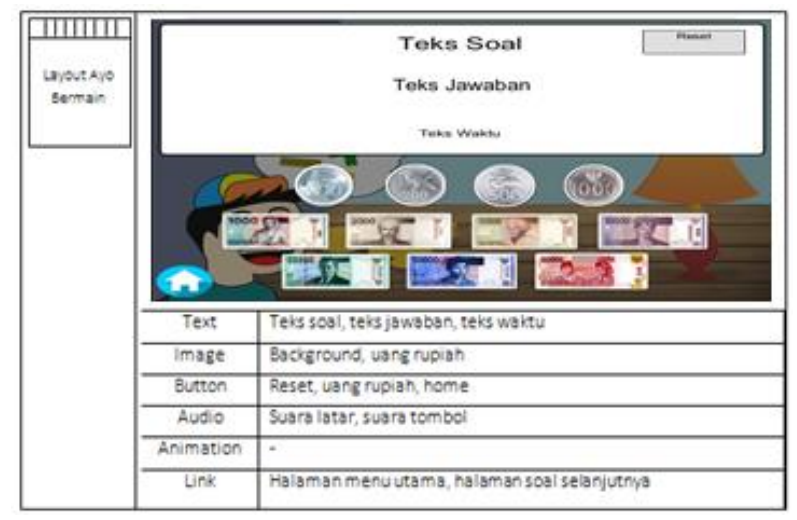

Gambar 15. Rancangan halaman menu Ayo Bermain

Tampilan rancangan halaman menu Panduan ditunjukkan oleh Gambar 16.

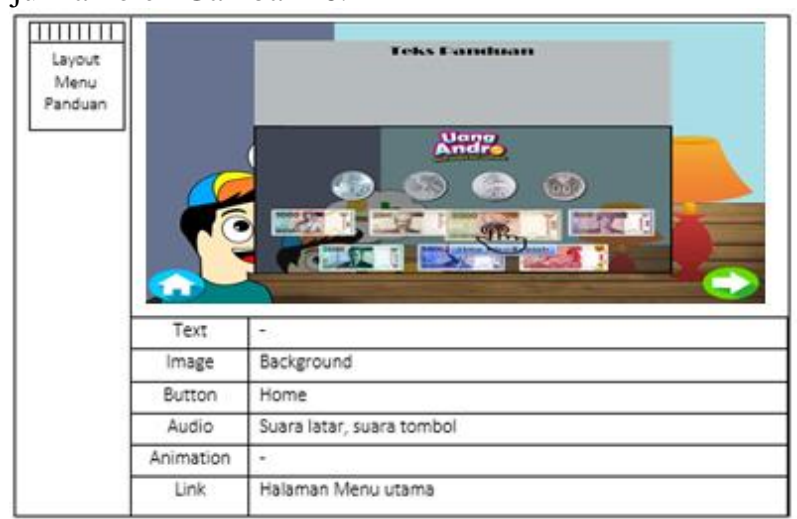

Gambar 16. Rancangan halaman тепи Panduan

\section{Pengumpulan Materi}

Merupakan proses untuk pengumpulan segala sesuatu yang dibutuhkan dalam proyek. Mengenai materi yang akan disampaikan, kemudian file-file multimedia seperti audio, video, dan citra yang akan dimasukkan dalam penyajian proyek multimedia tersebut.

Dalam tahap ini dilakukan pengumpulan materi berupa pembuatan gambar-gambar pendukung dengan menggunakan CorelDraw X6. Untuk bahan audio didapat dari internet kemudian diolah untuk dilakukan sedikit perubahan menggunakan perangkat lunak Audacity. Gambar-gambar pendukung seperti latar belakang permainan dan lainnya dibuat menggunakan perangkat lunak CorelDraw X6.

\section{Pembuatan}

Pembuatan permainan ini menggunakan perangkat keras serta perangkat lunak dengan spesifikasi sebagai berikut :

1. Perangkat Keras

a. Personal Computer (PC) atau Laptop

Perangkat keras yang digunakan dalam penelitian ini yaitu sebuah komputer laptop Sony Vaio SVE14132CVW White dengan spesifikasi sebagai berikut:

1. Prosesor Intel ${ }^{\circledR}$ Core $^{\mathrm{TM}} \mathrm{i} 3-3120 \mathrm{M}(2.50 \mathrm{GHz})$

2. Memori RAM 2,00 GB

3. Harddisk 320GB Serial ATA

4. Monitor LCD 14 Inchi

b. Smartphone 
Smartphone yang digunakan menggunakan sistem operasi Android dan sebagai pengujian aplikasi yang sudah jadi.

2. Perangkat Lunak

\section{a. Microsoft Windows 8}

Sistem Operasi dari laptop yang digunakan untuk membuat aplikasi mutimedia ini adalah Microsoft Windows 8 .

b. Construct 2

Merupakan tool yang digunakan untuk membuat permainan ini.

\section{c. Corel Draw X6}

Corel Draw X6 digunakan untuk merancang gambar pendukung permainan.

\section{d. Audacity versi 1.2.6}

Merupakan suatu editor audio digital yang bersifat open source digunakan untuk mengolah suara yang digunakan pada permainan.

5. Pengujian

Pengujian aplikasi dilakukan untuk mengetahui apakah aplikasi yang dibuat sudah sesuai dengan perancangan dan kebutuhan atau belum. Pengujian dilakukan pada tiap menu sebelum aplikasi selesai secara keseluruhan. Hal ini bertujuan agar apabila terdapat kesalahan fungsinya akan langsung dapat diperbaiki. Pengujian pada pembuatan aplikasi ini menggunakan pengujian kotak hitam. Sedangkan untuk menganalisis hasil pengujian ke pengguna menggunakan analisis regresi linier sederhana dan menggunakan uji hipotesis untuk mengambil suatu kesimpulan apakah suatu pernyataan dapat dibenarkan atau tidak.

\section{B. Metode Pengumpulan Data}

Metode pengumpulan data pada penelitian ini menggunakan tes. Tujuannnya, untuk mengetahui adakah pengaruh setelah siswa menggunakan aplikasi permainan pembelajaran.

Setelah data hasil tes diperoleh, maka data tersebut akan dianalisis menggunakan analisis regresi linier sederhana dengan melakukan uji hipotesis. Uji hipotesis dilakukan untuk mengambil suatu kesimpulan, apakah suatu pernyataan dapat dibenarkan atau tidak. Dalam penelitian ini ada dua macam hipotesis yang digunakan yaitu hipotesis nol $\left(\mathrm{H}_{0}\right)$ dan hipotesis alternatif $\left(\mathrm{H}_{1}\right)$.

\section{Teknik Analisis Data}

Data yang diperoleh selanjutnya dianalisis untuk didapatkan suatu kesimpulan. Dalam penelitian ini menggunakan analisis regresi linier sederhana. Data yang dikumpulkan akan diolah menggunakan bantuan software SPSS versi 16. Setelah itu menganalisis hasil output dari software SPSS dan melakukan uji hipotesis. Penelitian ini dikatakan berhasil, jika uji hipotesis menunjukkan model regresi yang dihasilkan cocok dan adanya pengaruh dari lama belajar yang signifikan terhadap hasil belajar.

\section{HASil PENELITIAN DAN PEMBAHASAN}

A. Hasil Pembuatan Permainan

Pembuatan permainan ini diimplementasi berdasarkan perancangan yang telah dibahas pada Bab III, sehingga dihasilkan suatu permainan yang bekerja sesuai dengan fungsinya. Sedangkan pengujiannya dilakukan dengan metode black-box, serta akan dilakukan juga uji coba permainan secara langsung ke pengguna menggunakan kuesioner. Berikut ini merupakan tampilan aplikasi yang telah dibuat. dibuat.

Berikut merupakan tampilan aplikasi permainan yang

\section{Halaman Menu Utama}

Setelah pengguna menunggu selama tiga detik pada halaman awal, akan muncul halaman selanjutnya yaitu halaman menu utama yang ditunjukkan pada gambar 17. Tampilan halaman menu utama terdiri dari gambar latar dan tombol-tombol menu utama permainan. Tombol menu utama utama tersebut antara lain menu Ayo Belajar, Ayo Mengingat, Ayo Bermain, Panduan, dan Keluar.

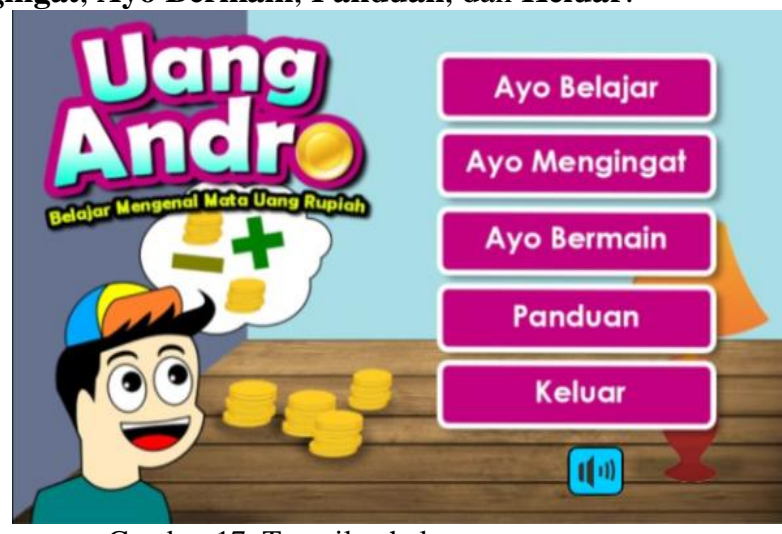

Gambar 17. Tampilan halaman menu utama

2. Halaman Menu Ayo Belajar

Apabila pengguna memilih menu Ayo Belajar, halaman yang akan ditampilkan adalah halaman menu Ayo Belajar seperti yang ditunjukkan pada Gambar 18. Pada halaman menu Ayo Belajar terdapat gambar mata uang rupiah yang terdiri dari uang logam dan uang kertas. Pengguna dapat menekan salah satu gambar uang rupiah tersebut dan akan muncul keterangan uang terbilang disertai dengan suara.

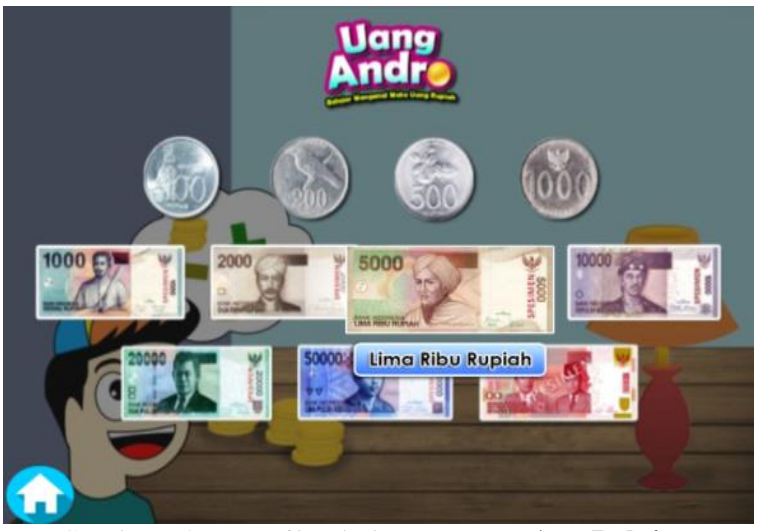

Gambar 18. Tampilan halaman тепи Ауо Belajar 


\section{Halaman Menu Ayo Mengingat}

Apabila pengguna memilih menu Ayo Mengingat, maka halaman selanjutnya yang akan ditampilkan adalah halaman pilih level seperti yang ditunjukkan pada Gambar 19. Pada halaman pilih level, terdapat dua level. Level pertama yang berisi kotak teka-teki 3x2 dan level kedua yang berisi kotak teka-teki $4 \times 3$.

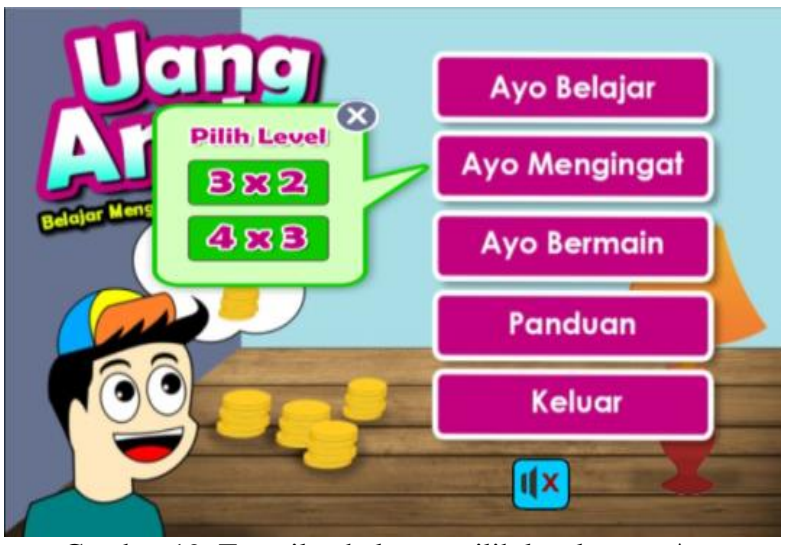

Gambar 19. Tampilan halaman pilih level mеnи Аyo Mengingat

Setiap level terdiri dari kotak teka-teki terdiri dari dua gambar yang kembar. Terdapat pewaktu dalam setiap level Ayo Mengingat. Pewaktu pada level pertama yaitu $3 \times 2$ terdapat pewaktu 15 detik dan pada level $4 \times 3$ terdapat pewaktu 30 detik. Tampilan level $3 \times 2$ ditunjukkan pada Gambar 20. dan tampilan level 4x3 ditunjukkan pada Gambar 21. Pengguna diminta untuk mencocokan dua kembar yang sama, jika semua kotak teka-teki telah habis dan waktu masih tersisa maka skor akan bertambah 1 kemudian sistem akan berulang menampilkan kotak teka-teki selanjutnya.

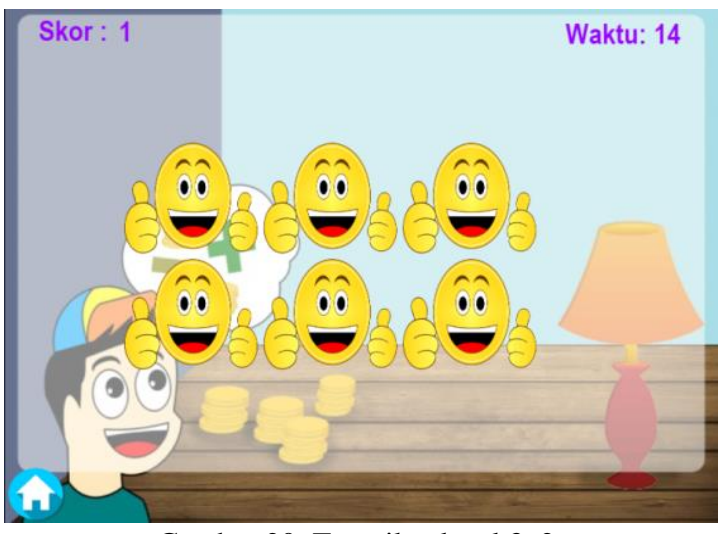

Gambar 20. Tampilan level 3x2

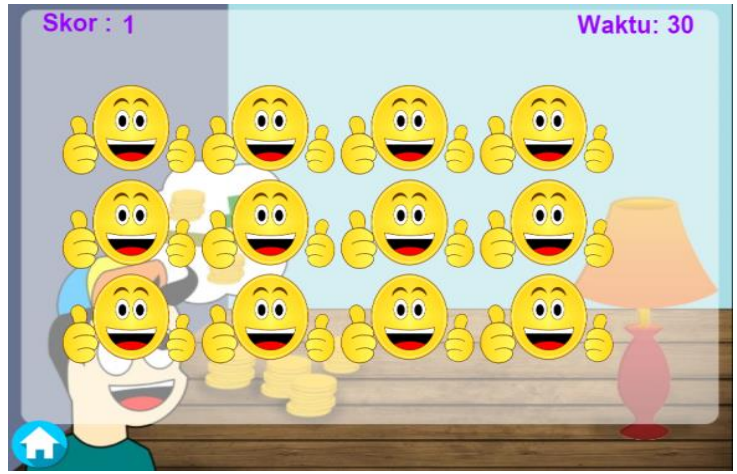

Gambar 21. Tampilan level 4x3
Jika waktu habis, maka akan muncul tampilan coba lagi dan total skor yang ditunjukkan pada Gambar 22

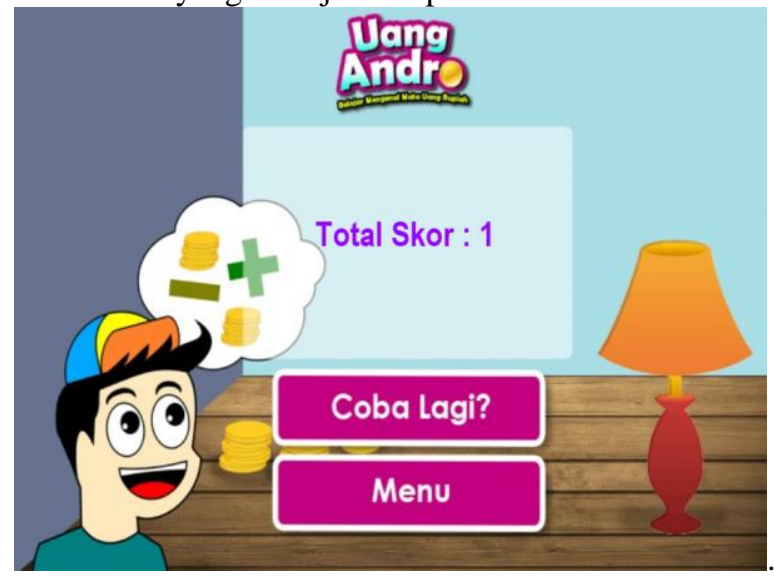

Gambar 22. Tampilan halaman permainan gagal

\section{Halaman Menu Ayo Bermain}

Apabila pengguna memilih menu Ayo Bermain, maka akan mumcul halaman selanjutnya yaitu pilih level permainan yang terdiri dari mudah, sedang, dan sulit. Tampilan pilih level menu Ayo Bermain ditunjukkan pada Gambar 23.

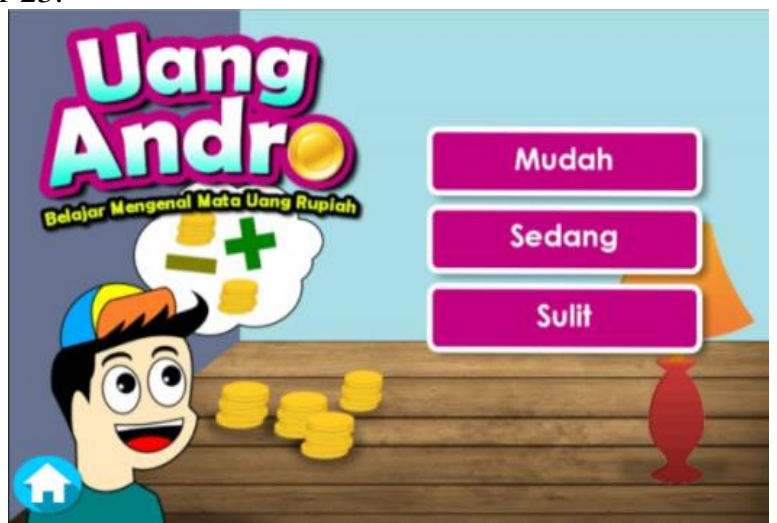

Gambar 23. Tampilan halaman pilih level menu Ayo Bermain

Setiap level terdapat soal perhitungan sesuai dengan level yang dipilih oleh pengguna. Perbedaan antara level mudah, sedang dan sulit terdapat pada soal dan pewaktu yang diberikan. Jika pengguna memilih level mudah maka akan diberikan pewaktu selama 20 detik untuk menjawab soal perhitungan. Pengguna dapat menjawab soal perhitungan dengan memilih gambar uang mana saja yang menjadi jawaban. Jika jawaban yang dipilih pengguna salah dan waktu masih tersisa, maka pengguna dapat menekan tombol reset yang ada di kanan atas. Tampilan permainan level mudah ditunjukkan pada gambar 24 . 


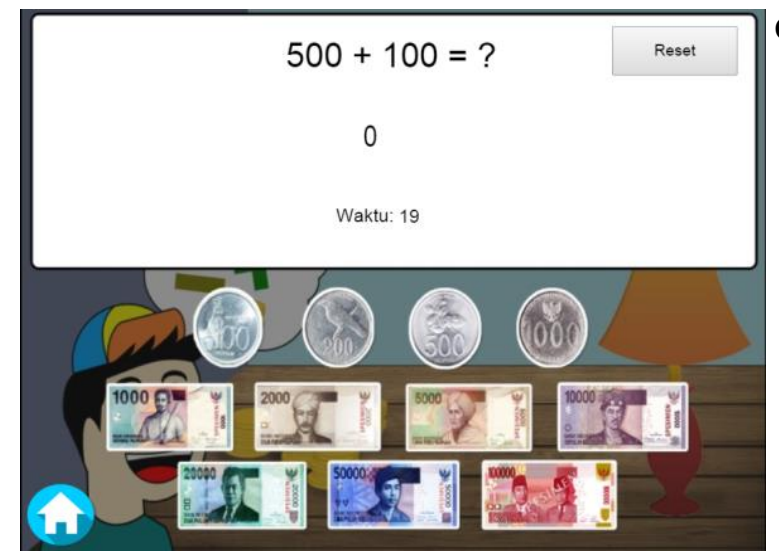

Gambar 24. Tampilan halaman menu Ayo Bermain

B. Pengujian aplikasi menggunakan metode black-box

Pengujian aplikasi permainan "UangAndro" yang telah dibuat dalam penelitian ini dilakukan dengan menggunakan metode black-box. Tahapan pengujian ini berisi rangkaian pengujian tombol dan fungsi yang terdapat dalam aplikasi. Pengujian ini dilakukan untuk memeriksa fungsi yang terdapat dalam aplikasi, apakah hasilnya sesuai dengan yang diinginkan. Pengujian ini juga dilakukan untuk mengetahui apakah masih terdapat kesalahan

dalam aplikasi ataukah masih terdapat kesalahan sehingga secepatnya dapat diberi solusi.

Pengujian dijalankan pada smartphone dengan sistem operasi android. Pengujian dilakukan dengan cara mengeksekusi source code dan kemudian diamati apakah hasilnya sesuai dengan spesifikasi kebutuhan. Hasil dari pengujian aplikasi ditunjukkan dengan tabel-tabel pengujian black-box.

Pengujian aplikasi dibuat berupa tabel pengujian kotak hitam dari menu yang ada dalam aplikasi. Berikut tabel pengujian fungsi umum aplikasi ditunjukkan pada Tabel 1. Tabel 1. Tabel Pengujian Fungsi Umum

\begin{tabular}{|l|l|l|c|}
\hline \multicolumn{1}{|c|}{$\begin{array}{c}\text { Nama } \\
\text { Pengujian }\end{array}$} & \multicolumn{1}{|c|}{$\begin{array}{c}\text { Bentuk } \\
\text { Pengujian }\end{array}$} & $\begin{array}{c}\text { Hasil yang } \\
\text { Diharapkan }\end{array}$ & $\begin{array}{c}\text { Hasil } \\
\text { Pengujian }\end{array}$ \\
\hline $\begin{array}{l}\text { Pengujian } \\
\text { halaman awal }\end{array}$ & $\begin{array}{l}\text { Menunggu } 3 \\
\text { detik untuk } \\
\text { berpindah } \\
\text { halaman }\end{array}$ & $\begin{array}{l}\text { Tampil halaman } \\
\text { menu utama }\end{array}$ & Berhasil \\
\hline $\begin{array}{l}\text { Pengujian } \\
\text { menu Ayo } \\
\text { Belajar }\end{array}$ & $\begin{array}{l}\text { Menekan } \\
\text { tombol Ayo } \\
\text { Belajar }\end{array}$ & $\begin{array}{l}\text { Tampil halaman } \\
\text { Ayo Belajar }\end{array}$ & Berhasil \\
\hline $\begin{array}{l}\text { Pengujian } \\
\text { menu Ayo } \\
\text { Mengingat }\end{array}$ & $\begin{array}{l}\text { Menekan } \\
\text { tombol Ayo } \\
\text { Mengingat }\end{array}$ & $\begin{array}{l}\text { Tampil popup } \\
\text { level Ayo } \\
\text { Mengingat }\end{array}$ & Berhasil \\
\hline $\begin{array}{l}\text { Pengujian } \\
\text { menu Ayo } \\
\text { Bermain }\end{array}$ & $\begin{array}{l}\text { Menekan } \\
\text { tombol Ayo } \\
\text { Bermain }\end{array}$ & $\begin{array}{l}\text { Tampil halaman } \\
\text { pilih level Ayo } \\
\text { Bermain }\end{array}$ & Berhasil \\
\hline $\begin{array}{l}\text { Pengujian } \\
\text { menu Keluar }\end{array}$ & $\begin{array}{l}\text { Menekan } \\
\text { tombol } \\
\text { Keluar }\end{array}$ & $\begin{array}{l}\text { Keluar dari } \\
\text { aplikasi }\end{array}$ & Berhasil \\
\hline
\end{tabular}

C. Analisis lama belajar dan hasil belajar menggunakan analisis regresi linier sederhana dengan uji hipotesis

Analisis data dalam penelitian ini dengan menggunakan analisis regresi linier sederhana. Regresi linier sederhana digunakan untuk mengukur pengaruh satu variabel bebas $(\mathrm{X})$ dan variabel terikat $(\mathrm{Y})$. Pada analisis ini variable $\mathrm{X}$ dan $\mathrm{Y}$ diperoleh dari lama belajar dan hasil belajar. Lama belajar sebagai variabel $X$, sedangkan hasil belajar sebagai variabel Y. Data yang diperoleh untuk dianalisis yaitu siswasiswi Sekolah Dasar kelas II. Terdapat 25 siswa yang dijadikan sampel pada penelitian ini.

Berikut hasil olah data lama belajar dan hasil belajar dengan menggunakan bantuan software SPSS versi 16.
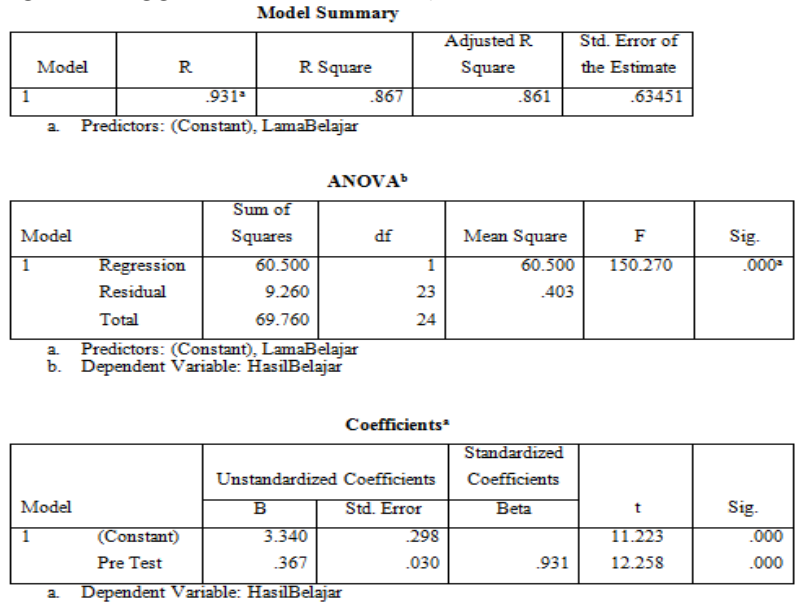

Gambar 25. Hasil output keseluruhan olah data menggunakan SPSS 16

Berdasarkan gambar 27. Pada tabel Model Summary dapat disimpulkan besarnya nilai korelasi atau hubungan (R) sebesar 0,931. Besarnya pengaruh dapat dilihat dari $\mathrm{R}$ Square yaitu sebesar 0,867 yang mengandung pengertian bahwa $86,7 \%$ variabel lama belajar(X) mempengaruhi variabel hasil belajar dan sisanya sebesar $13,3 \%$ dipengaruhi oleh faktor lain. Pada gambar 27. di tabel ANOVA juga dapat disimpulkan pada uji $\mathrm{F}$ menunjukkan bahwa nilai sig. $(0,000)$ $<\alpha(0,05)$ maka $\mathrm{H}_{0}$ ditolak yang berarti model cocok, dimana variabel lama belajar dapat memprediksi varibel hasil belajar. Sedangkan pada tabel Coefficients menunjukkan bahwa konstanta a yaitu 3,340 dan koefisien b didapat dari baris nilai pre-test yaitu 0,367 . Sehingga persamaan regresinya dapat ditulis :

$$
\mathrm{Y}=\mathrm{a}+\mathrm{bX} \text { atau } \mathrm{Y}=3,340+0,367 \mathrm{X}
$$

Dari persamaan diatas dapat diterjemahkan :

- Konstanta sebesar 3,340 menyatakan bahwa jika tidak ada lama belajar(X), maka hasil belajarnya (Y) sebesar 3,340

- Koefisien X sebesar 0,367 menyatakan bahwa setiap penambahan 1 nilai $\mathrm{X}$, maka nilai hasil belajar(Y) bertambah sebesar 0,367

Pada tabel coefficients dapat disimpulkan dari uji $t$ adalah nilai sig. $(0,000)<\alpha(0,05)$ maka $\mathrm{H}_{0}$ ditolak yang berarti ada pengaruh nyata (signifikan) varibel lama belajar(X) terhadap variabel hasil belajar(Y).

Berikut hasil kurva menggunakan analisis regresi linier sederhana : 


\section{Normal P-P Plot of Regression Standardized Residual}

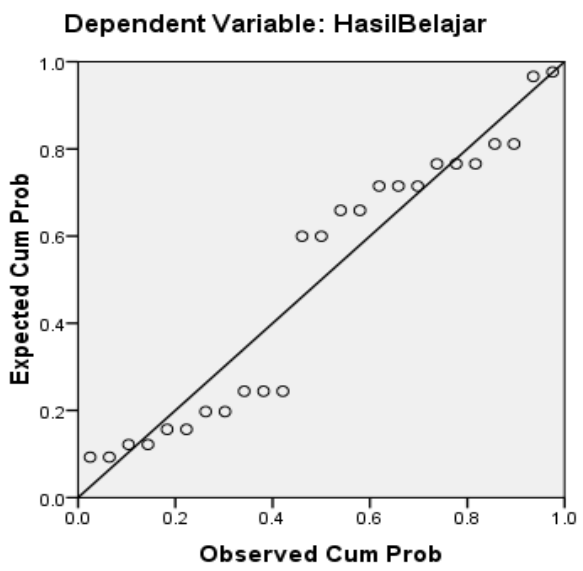

Gambar 26. Kurva hasil analisis regresi linier sederhana

Hasil kurva menunjukkan garis regresi linier sederhana yang menghubungkan kedua variabel. Titik-titik pada kurva merupakan estimasi dari sebaran data yang diperoleh dari persamaan regresi. Jadi setiap data dimasukkan ke dalam persamaan regresi yang telah didapatkan pada tabel coefficient, kemudian hasil dari persamaan tersebut ditunjukkan pada gambar 26.

\section{PENUTUP}

\section{A. Kesimpulan}

Kesimpulan dari penelitian Tugas Akhir ini adalah sebagai berikut

1. Aplikasi permainan "UangAndro" sebagai pengenalan mata uang rupiah yang dapat melatih kemampuan anak dalam berhitung menggunakan media mata uang rupiah sudah berhasil dirancang dan dibangun menggunakan Construct 2.

2. Berdasarkan hasil pengujian aplikasi menggunakan Uji Kotak Hitam (Black Box Test), menunjukkan bahwa permainan sudah berjalan sesuai spesifikasi kebutuhan yang menampilkan hasil uji pada tiap fungsi aplikasi dan tombol.

3. Berdasarkan uji hipotesis t, dapat disimpulkan bahwa adanya pengaruh nyata (signifikan) varibel lama belajar terhadap variabel hasil belajar siswa.

B. Saran

Saran yang dapat digunakan untuk penelitian lebih lanjut adalah sebagai berikut.

1. Perlu dilakukan penelitian lanjutan untuk mengembangkan aplikasi "UangAndro" menggunakan sistem operasi pada perangkat lain.

2. Tampilan aplikasi "UangAndro" hanya diam dan statis, diharapkan dapat ditambah efek animasi sehingga membuat aplikasi ini semakin menarik.

\section{DAFTAR PUSTAKA}

[1] Ariesto Hadi, S., Multimedia Interaktif Dengan Flash. Yogyakarta: Graha Ilmu, 2003.
[2] Bank Indonesia, Direktorat Pengedaran Uang, Buku Panduan Uang Rupiah. Jakarta: 2011.

[3] Binanto, I., Multimedia Digital: Dasar Teori dan Pengembangannya, Andi, Yogyakarta, 2010

[4] Caterin, R., Aplikasi Multimedia Dalam Pembelajaran Teknologi Informasi dan Komunikasi (TIK) Materi Hardware Berbasis Flash Untuk Sekolah Menengah Atas. Tugas Akhir pada prodi Sistem Komputer FT Undip, Semarang: Tidak diterbitkan, 2014.

[5] Galih Hermawan, Arizonanataliya Heryanti, "Game Shopping Time", Jurnal Ilmiah Komputer dan Informatika Vol.2 No.1, Program Studi Teknik Informatika UNIKOM, 2013.

[6] Ghozali, Imam, Aplikasi Analisis Multivariate dengan Program IBM SPSS 19, Badan Penerbit Universitas Diponegoro,2011.

[7] Hanifa Naufaliawan, A., Pengembangan Permainan Untuk Pembelajaran Angka dan Huruf Hijaiyah Berbasis Android. Skripsi S-1, Teknik Sistem Komputer Unversitas Diponegoro, Semarang, 2015.

[8] Hasan, Iqbal, Analisis Data Penelitian Dengan Statistik, PT Bumi Aksara, 2004.

[9] http://audacity.sourceforge.net. [Accessed: 12-Mar-2015].

[10] Madcoms, Kupas Tuntas Corel Draw X6. Andi, 2012.

[11] Riyanto, Agus, Pengaruh Pemberian Pre-test dan Post-test Terhadap Hasil Belajar Matematika Siswa pada Materi Bilangan Pecahan Kelas VII MTs Bandung, Tulungagung. Skripsi S-1, Sekolah Tinggi Agama Islam Negeri (STAIN), Tulungagung, 2012.

[12] Simon, J., Head First Android Development. O'Reilly Media, Inc, 2012.

[13] Suseno, S., Uang : Pengertian, Penciptaan, dan Peranannya Dalam Perekonomian. Jakarta: Pusat Pendidikan dan Studi Kebanksentralan (PPSK) BI, 2002.

[14] Suharjo, Bambang, Analisis Regresi Terapan Dengan SPSS, Graha Ilmu, 2008.

[15] Susanto, Djumantoro, Pembuatan Game Edukatif Pembelajaran Mata Uang Rupiah untuk Anak Prescholl. Skripsi S-1, Universitas Surabaya, Surabaya, 2012.

[16] Susilana, Rudi, dan Riyana, Cepi., Media Pembelajaran: Hakikat, Pengembangan, Pemanfaatan, dan Penilaian, CV. Wacana Prima, 2009.

[17] Suyanto, M., Multimedia: Alat untuk Meningkatkan Keunggulan Bersaing. Yogyakarta: Andi, 2009.

[18] Tay, Vaughan, Multimedia : Making It Work, Edisi 6. Yogyakarta : Penerbit Andi Offset, 2006.

[19] Wiratmoko, Ario, Pengaruh Kegiatan Ekstrakuriler Robotika Terhadap Kecerdasan Emosional Siswa Di SMK Negeri Yogyakarta, Jurnal Penelitian, Universitas Negeri Yogyakarta, 2012. 